\title{
PER CAPITA INCOME INEQUALITY IN CZECH HOUSEHOLDS BEFORE, DURING AND AFTER THE ECONOMIC AND FINANCIAL CRISIS
}

\author{
Markéta Hnízdilová1, Václav Adamec ${ }^{1}$ \\ ${ }^{1}$ Department of Statistics and Operation Analysis, Faculty of Business and Economics, Mendel University in Brno, \\ Zemědělská 1, 61300 Brno, Czech Republic
}

Link to this article: https://doi.org/10.11118/actaun202068050885

Received: 29. 8. 2019, Accepted: 4. 9. 2020

To cite this article: HNÍZDILOVÁ MARKÉTA, ADAMEC VÁCLAV. 2020. Per Capita Income Inequality in Czech Households Before, During and After the Economic and Financial Crisis. Acta Universitatis Agriculturae et Silviculturae Mendelianae Brunensis, 68(5): 885-899.

\begin{abstract}
The study tackles the issue of distribution inequality in equalized per capita income in households defined by multiple grouping criteria in the Czech Republic before, during and after the economic and financial crisis. The factors were economic status of the household head, number of children, education and the NUTS 3 administrative regions. Interval grouped per capita income data assembled within the EU-SILC framework via quota sampling were received from czso.cz for 2008, 2012 and 2016. Indicators of income level, variation, quantiles, medial and Gini index were calculated for the respective household groups. Income concentration in the Czech Republic is considerably low among OECD states and still decreasing due to government social and economic policy and favourable phase of the economic cycle. The largest income inequality was detected in the self-employed, jobless and qualified employees, households with 3 or more children, single-parent families with dependants, households with one or both tertiary educated parents or households residing in Prague or Středočeský region. The threat of poverty is imminent in the jobless, economically inactive pensioners, unqualified labourers and households with 3 or more children. Geographically, the poverty affects households mostly in Moravskoslezský or Ústecký regions. Government measures evidently helped reduce income inequality, poverty and social exclusion in Ústecký region in 2008. The least affected regions by poverty were Prague and Středočeský region. Significant differences in income level or concentration of income distributions by regional and other household grouping criteria were revealed.
\end{abstract}

Keywords: equalized per capita income, inequality, Gini index, LSDV model, Scheffé test, quartiles, medial

\section{INTRODUCTION}

In the period following 1989, household income in the Czech Republic experienced a sizeable nominal growth that followed after many years of no change under the inefficient, utterly centralized and state-owned economy. Hand-in-hand with privatization and liberalization of the economy the Czech households experienced increased differentiation of salaries, wages and social benefits as a result of deregulation and exposure of the labor costs to market forces. In several years, this led to visible differentiation in economic and social status among the Czech households and contributed to appearance of new phenomena, such as material and social deprivation, poverty, augmented crime rate, divorce rate, homelessness and social exclusion.

In terms of the country's wealth distribution, the Czech Republic belongs to the high income equality group together with the Scandinavian countries, Iceland and Slovakia (Tichá, 2015). These countries 
for historical reasons apply a significant regulation of the wage differentiation in both public and private sectors and use extensive social transfers to mitigate differences between the rich and the poor. The state also oversees access to housing, general health care, education and vocational training and regulates utilization of the natural resources. Wilkinson and Pickett (2010) favor greater equality of income, as it leads to greater overall prosperity, living standard, general health and reduction of undesirable phenomena, such as crime, violence, social instability or substance abuse, etc. Graafland and Lous (2018) conclude that greater income inequality contributes to lower life satisfaction. Petrúšek (2018) noted that public acceptance of income inequality rises with earnings level, economic activity and highest attained education, but drops with age. Support for social income transfers is generally higher in cohorts which could potentially benefit from such support. Increasing minimum wage and income equality contributes to a higher support for the government in power (Belabed and Hake, 2018).

For the Czech state, the policies currently mean one of the lowest levels of income inequality in the world (Gini index $\approx 0.25$ ) and very low income poverty rate $(9.1 \%$ in 2017), as defined by the boundary of $60 \%$ equalized median personal income. For comparison, Gini index for household income in EU is 0.3. The Czech households attain below average levels of material deprivation, currently 16.5\%, compared with $22.4 \%$ in the EU. Materially deprived household is defined by inability to meet three or more criteria (out of nine) set forth by the European Commission (Stávková and Antošová, 2013). Severe material deprivation is established, when four or more criteria were unfulfilled. In general, material deprivation and poverty tend to concur: about $72 \%$ households affected by poverty meet the conditions for material deprivation.

Birčiaková et al. (2013) indicate that negative consequence of the more regulated income approach in the Czech Republic may be declining motivation to work for the low income subjects, as their pay tends to grow more slowly than in the economically inactive groups: the unemployed and the pensioners. In their view, France and Finland solved this problem by lifting up the low income bracket in pensioners. A similar problem also exists in the ever growing population segment (approx. 800 thous.) endangered by indebtedness and threat of personal bankruptcy, which demotivates the affected to seek employment or even switch to better paying job. Incidence of low economic activity is related to income poverty and material deprivation, since households of the economically inactive population often receive the lowest income.

Among the European countries, income inequality and increased poverty rate is a significant problem mainly for the southern states (Bulgaria, Romania,
Spain, Italy, Portugal and Greece), but also in Poland, the Baltic states, UK and Ireland. The Scandinavian countries and the Netherlands, on the other hand, reach very low levels of poverty. Slovakia is also known for comparatively low poverty level, similar to the Czech Republic (Longford et al., 2010). It should be mentioned, that during 2002 to 2007 Czechia experienced the most dynamic increase of private income in history due to domestic and foreign economic boom and the country's accession to EU. In the following period 2011-2015, the nominal income increased, but at slower rate, with greater income differentiation and poverty rates, especially for the unemployed and the pensioners.

Objective of the study is to assess changes in level and concentration of the per capita income in households of the Czech Republic, defined by various grouping criteria. Focus shall be paid to the types of households that have specific needs, display typical behavioral patterns and with increased incidence of poverty. From the point of the financial and economic crisis, the paper shall look into changes of income level and inequality since the onset of the crisis in 2008; in year 2012, when the Czech economy experienced "double bottom" in economic output and after the crisis in 2016, when the economy recovered. Differences in income and concentration among household groups defined by discrete criteria, such as economic activity, attained education, number of children and geography shall be statistically tested.

The paper is expected to bring innovative information about dynamics of the per capita income in periods shortly before, during and after the economic crisis, concurrent austerity measures launched by the Czech government in response to the economic downturn, low revenues from taxes or changes in the VAT, personal income and corporate tax rates. Although impact of the economic growth, government spending cuts and overhaul of the tax system on household income and consumption could not be independently quantified, the study brings new knowledge about development of the income concentration measures in the period since 2008 and the perils of social exclusion and poverty in particular deprived groups that stem from uneven distribution of the country's wealth.

\section{MATERIALS AND METHODS}

To tackle the objectives of the paper, we considered per capita net incomes for Czech households recorded by the Czech Statistical Office (czso.cz) by multiple discrete grouping criteria. The incomes include regular earnings from economic activity, social transfers, pensions, stipends, sickness or unemployment benefits, rent and interest on deposits. The data were collected via quota sampling from a preselected group of households that were identified in 14 administrative regions (NUTS 3) of the Czech Republic based on respective 
population size. The sampling unit was a household occupying a single apartment, where the members jointly participate on covering the operating costs. The data collection and statistical investigation of the incomes, living standards incidence of poverty, social exclusion and other types of material and financial deprivation is recurrently carried out by the CZSO within the EU-SILC framework. Apart from the Czech Republic, this investigation covers all countries of the European Economic Area (EEA). The information collected is used to assist more precise targeting of the government economic and social programs, measures to deal with unemployment, parameters of the tax system and management of social transfers.

The income data were published by the CZSO in an interval grouped form and represented empirical distributions of the incomes with available interval boundaries, midpoints and relative household proportions. To cover the periods immediately before, during and after the economic and financial crisis, the data were retrieved for calendar years 2008, 2012 and 2016. The available factors of household grouping were household size, presence of economically active member, presence of member involved in independent entrepreneurship (self-employed), an economically inactive pensioner, juvenile dependent under 25, unemployed family member, head of the household economic status, the highest attained education, type of the household and geography.

Numerous statistical methods were previously developed to illustrate income inequality and help determine the risk of poverty. Many methods are based on summarizing the empirical income distributions to produce comparable indicators of income concentration, such as Atkinson (2016) inequality index, Robin Hood index, Theil index (Cowell, 2000), entropy index, $C V$ and others. Important illustration of income concentration method offers the Lorenz concentration curve (Fig. 1) depicting the cumulative relative totals on the vertical against the cumulative relative frequencies on the horizontal. Both quantities are derived from the income data and help define the Gini concentration index $G$ as

$G=\frac{A}{A+B} \in[0 ; 1]$

$45^{\circ}$ line indicates an idealized theoretical distribution with absolute equality (all subjects possess the same). The Lorenz curve and the idealized $45^{\circ}$ line delimit the area (A) representing the base for calculation of the Gini index. Zero $G$ index corresponds to the perfect equality scenario, when all subjects receive exactly the same amount. On the other hand, $G$ value close to unity implies maximum inequality, when a single subject receives the entire income, while others acquire none. For income data grouped into $k$ intervals, the Brown (1994) formula for $G$ calculation in (2) appears the most appropriate

$G=\left|1-\sum_{i=2}^{k}\left(x_{i}-x_{i-1}\right)\left(y_{i}+y_{i-1}\right)\right|$,

where $x_{i}$ denotes the cumulative relative frequencies of the $i$-th interval, $i=1,2, \ldots, k$, and $y_{i}$ are the cumulative relative totals. It holds that $x_{0}=y_{0}=0$ and $x_{k}=y_{k}=1$.

The approach to assess income inequality through Gini index, in general, has several advantages (Charles-Coll, 2011): $G$ metric is independent of the scale, it is unaffected by the population size or the absolute income level and, consequently, can be used to compare income distributions in various subcategories or two or more periods. A transfer of any positive amount from the poor subjects to the rich ones shall increase the Gini index.

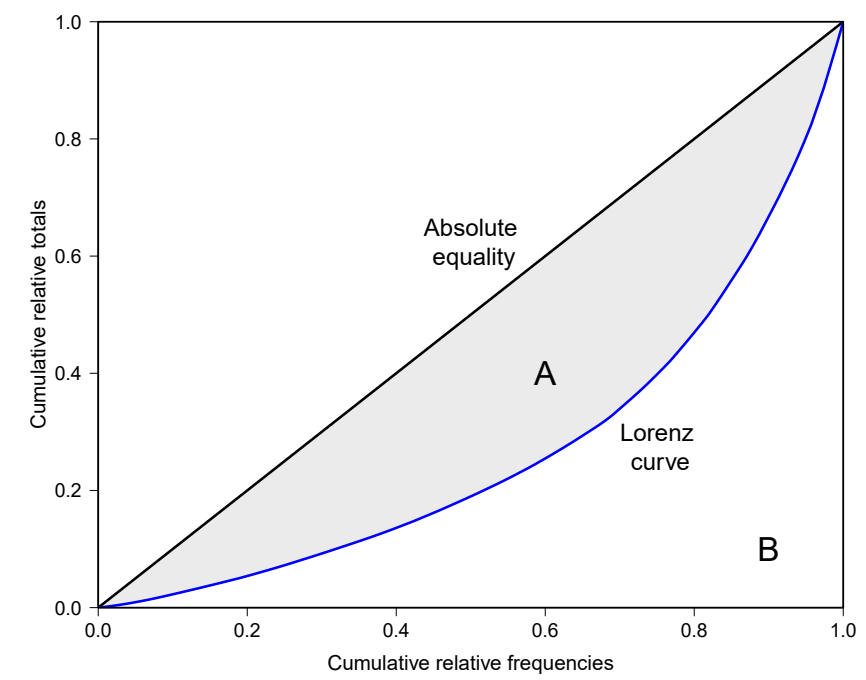

1: Diagram of the Lorenz concentration curve and graphical representation of the Gini index, as adopted from Charles-Coll (2011) 
Nonetheless, a specific value of Gini index may in theory relate to different shapes of the Lorenz curve and suggest equality of several distinct distributions. In terms of population quantiles, the income frequencies may, however, be different. Furthermore, Gini coefficients obtained from several geographic regions, likely heterogeneous in terms of income, cannot be simple or weight averaged to produce a pooled inequality measure for the whole entity (Charles-Coll, 2011).

Since value of the Gini index is somewhat related to the variability of incomes, weighted formulas for mean and variance of the income distribution were applied on the interval grouped data. Quantiles $x_{p}$ were obtained from the interval frequency tables following the formula in Minařík et al. (2013)

$x_{p}=d_{p}+\frac{p-k_{p-1}}{p_{p}} \times h$,

where $d_{p}$ symbolizes the lower boundary of the income interval, $p \in[0,1]$ is probability associated with $x_{p}$ quantile, $k_{p-1}$ is cumulative relative frequency of the preceding interval, $p_{p}$ relative frequency of the income class and $h$ the interval width. Formula (3) was specifically applied to obtain the income quartiles from the tabulated data. In the modified form (4), it helped derive the medial, the income value that separates the lower 50\% cumulative totals from the remaining sum

$$
x_{M}=d_{M}+\frac{0.5-k q_{M-1}}{\frac{X_{M} n_{M}}{\sum_{i=1}^{k} x_{i} n_{i}}} \times h,
$$

where $d_{M}$ is the lower boundary of the medial interval, $k q_{M-1}$ is cumulative relative total of the preceding class,

$$
\frac{x_{M} n_{M}}{\sum_{i=1}^{k} x_{i} n_{i}}
$$

the relative total of the medial class and $h$ is the interval width. It holds, that $x_{M} \geq x_{0.50}$. Equality of medial and median is anticipated, when minimum income concentration, i.e. maximum equality, occurs $(G=0)$.

Linear models of two-way Anova (5) shown in Ott (1993) with main effects were constructed and estimated by OLS to ascertain simultaneous statistical significance of the household grouping factor $A$ with levels $\alpha_{i}, i=1,2, \ldots, p$ and factor $B$ (year) with levels $\beta, j \stackrel{=}{=} 1,2, \ldots, m$. $\mu$ symbolizes the constant, factor $A$ is a specific discrete household grouping criterion and $\varepsilon_{i j k}$ a random term with assumed distribution $\mathrm{N}\left(0, \sigma_{\varepsilon}^{2}\right)$.

$y_{i j k}=\mu+\alpha_{i}+\beta_{j}+\varepsilon_{i j k}$.
Since there was only one observation per combination of levels $i$ and $j, k=1$ and two-way interactions were not estimable. The model terms were treated fixed, since the impact of administrative regions or years were thought to be related to the data design and interest was primarily in differences between specific levels of the fixed effects. The two-way Anova is technically equivalent to the Least Squares Dummy Variable (LSDV) model of panel data in the non-centered form, with crosssectional units and time variable dummies. The LSDV model assumes time-invariant constants for each cross-sectional entity and unstructured time effects, as described in Baltagi (2005).

The ANOVA model (5) was implemented to estimate the levels of income or concentration for respective household grouping categories and test differences among the means with the conservative Scheffé post-hoc test (Scheffé, 1959). Results were presented in form of homogeneous groups identified by common letter. Due to insufficient sample size and reduced power, non-parametric methods were avoided in the current study.

Calculation of the income concentration indicators, linear model estimation, statistical tests and construction of diagrams were carried out with ineq package by Zeileis (2014), agricolae library by de Mendiburu (2020), lattice library by Sarkar (2008), stats core library of the $R$-software, version 3.6.3 (r-project.org).

\section{RESULTS AND DISCUSSION}

\section{Economic Status of Household Head}

During the period under exploration, the mean, median and medial incomes were progressively increasing between 2008, 2012 and 2016 in all categories by the economic status of the household head (see Tabs. I and II). The largest levels of per capita household income were observed in the segment of the qualified employees and in the selfemployed. This finding underlines the importance of economic activity for economic status of the household. It is nevertheless known, that mean income is regularly found in proximity of the $66 \%$ percentile and consequently around $2 / 3$ households attain lower per capita income than the mean. Few studies noticed that income of the self-employed generally shows higher dependency on the economic cycle and, therefore, it is prone to display greater volatility over time. Lower and upper quartiles for the per capita income by household head categories are shown in Fig. 2 . The reader may notice the impact of income redistribution on the lower quartile.

The lowest incomes were detected in the unemployed group and economically inactive pensioners in all years in this study. Since the median incomes were lower than the respective means in all categories, it could be concluded that distributions of equalized per capita incomes were 
I: Descriptive statistics of per capita income of Czech households (CZK) by economic status of the household head

\begin{tabular}{|c|c|c|c|c|c|c|}
\hline \multirow{2}{*}{ Category } & \multicolumn{2}{|c|}{2008} & \multicolumn{2}{|c|}{2012} & \multicolumn{2}{|c|}{2016} \\
\hline & Mean & SD & Mean & SD & Mean & SD \\
\hline Employees total & 12,321 & 6,214 & 14,476 & 7,849 & 15,951 & 8,023 \\
\hline Employees unqualified & 10,591 & 4,550 & 11,751 & 5,039 & 13,366 & 5,588 \\
\hline Employees qualified & 14,061 & 7,160 & 16,491 & 8,819 & 17,661 & 8,847 \\
\hline Self-employed & 13,681 & 9,625 & 14,501 & 9,255 & 16,898 & 10,064 \\
\hline Pensioners total & 9,568 & 3,730 & 12,011 & 3,881 & 12,881 & 3,668 \\
\hline Pensioners economically active & 10,903 & 4,813 & 13,313 & 4,971 & 14,528 & 4,740 \\
\hline Pensioners economically inactive & 9,346 & 3,503 & 11,868 & 3,736 & 12,723 & 3,515 \\
\hline Unemployed & 6,091 & 4,496 & 7,073 & 4,668 & 7,291 & 4,467 \\
\hline
\end{tabular}

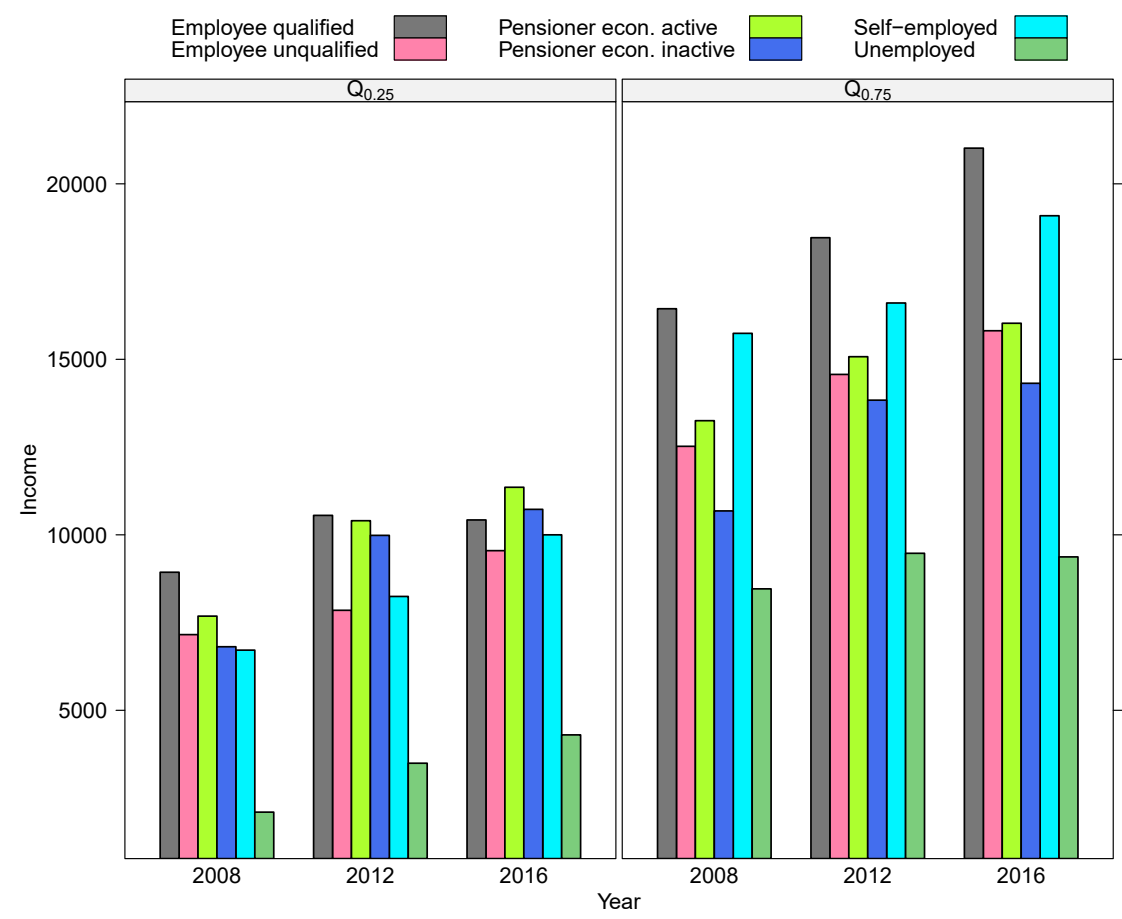

2: Lower (left) and upper (right) quartiles for the per capita household income (CZK) by economic status of the household head (category) in 2008, 2012 and 2016

positively skewed. The biggest income variation (SD) was observed in the self-employed, with an overall upward trend, although the relative variability gradually decreased in all household head categories over time.

Since medial exceeded the value of median in all categories (Tab. II), a positive value of Gini coefficient could be expected. The largest income inequality was seen in the unemployed and the self-employed segments, though comparatively high $G$ index was also found among the qualified employees (Tab. III). High inequality of income distribution in this group likely occurred as a result of employees with tertiary degree, who often receive compensation in the right tail of the combined distribution and thus contribute to greater concentration of the per capita household income. There is evidence that attained qualification in economically active household members increases the absolute level of income in the educated employees, which lowers the chance for material deprivation or income poverty, though still contributes to the overall inequality of income, as noted in Brázdilová and Švarcová (2015).

The per capita income of employees showed slight increase of income concentration in 2012 relative to 2008, but then displayed drop in 2016 (Tab. III). In other groups, the Gini index slightly decreased between 2008 and 2016. During the financial and economic crisis, the Czech government introduced a series of austerity measures to cope with declining tax revenues caused by the economic slowdown. As a result, access of households to social benefits and their regular increase were curtailed. Also, the government slightly relaxed the restrictions on pay 
II: Median and medial of per capita income of Czech households (CZK) by economic status of the head of the household

\begin{tabular}{lrrrrrrr}
\hline \multirow{2}{*}{ Category } & \multicolumn{2}{c}{2008} & \multicolumn{2}{c}{2012} & \multicolumn{2}{c}{2016} \\
\cline { 2 - 5 } \cline { 6 - 8 } & Median & Medial & & Median & Medial & Median & Medial \\
\hline Employees total & $11,202.3$ & $13,728.3$ & $12,917.9$ & $16,176.5$ & $14,183.4$ & $17,673.5$ \\
\hline Employees unqualified & $9,839.1$ & $11,917.5$ & $11,209.7$ & $13,181.8$ & $12,681.7$ & $14,624.7$ \\
\hline Employees qualified & $12,687.7$ & $15,815.5$ & $14,509.5$ & $18,495.8$ & $15,720.3$ & $19,572.6$ \\
\hline Self-employed & $11,227.4$ & $15,882.4$ & $12,424.7$ & $16,938.8$ & $14,545.5$ & $19,826.7$ \\
\hline Pensioners total & $8,903.2$ & $10,115.7$ & $11,989.0$ & $12,651.1$ & $12,618.0$ & $13,168.7$ \\
\hline Pensioners economically active & $10,467.7$ & $11,864.1$ & $12,738.3$ & $13,874.5$ & $13,691.6$ & $14,847.8$ \\
\hline Pensioners economically inactive & $8,746.1$ & $9,787.6$ & $11,910.6$ & $12,529.2$ & $12,521.6$ & $13,026.3$ \\
\hline Unemployed & $5,279.9$ & $8,140.5$ & $6,483.3$ & $9,142.2$ & $6,835.7$ & $8,856.0$ \\
\hline
\end{tabular}

III: Per capita income inequality (G coefficients) for Czech households by economic status of the head of the household

\begin{tabular}{llll}
\hline \multicolumn{1}{c}{ Category } & 2008 & 2012 & 2016 \\
\hline Employees total & 0.250 & 0.266 & 0.253 \\
Employees unqualified & 0.217 & 0.220 & 0.216 \\
Employees qualified & 0.258 & 0.270 & 0.258 \\
Self-employed & 0.330 & 0.314 & 0.308 \\
Pensioners total & 0.161 & 0.144 & 0.124 \\
Pensioners economically active & 0.189 & 0.182 & 0.158 \\
Pensioners economically inactive & 0.153 & 0.137 & 0.117 \\
Unemployed & 0.350 & 0.336 & 0.311 \\
\hline
\end{tabular}

IV: Homogeneous groups based on two-tailed post-hoc test by Scheffé for differences in the mean per capita income (left) and concentration of per capita income (right) among households grouped by the economic activity of the household head. Differences between the household types by economic activity with the same letter are not statistically significant $(\alpha=0.05)$

\begin{tabular}{lccccccc}
\hline \multicolumn{1}{c}{ Economic activity } & Mean income & Groups & & \multicolumn{2}{c}{ Economic activity } & Average $G$ & Groups \\
\hline Employees qualified & 16071.0 & a & Unemployed & 0.332 & a \\
Self-employed & 15026.7 & a & Self-employed & 0.317 & $\mathrm{a}$ \\
Pensioners economically active & 12914.7 & $\mathrm{~b}$ & Employees qualified & 0.262 & $\mathrm{~b}$ \\
Employees unqualified & 11902.7 & $\mathrm{~b}$ & Employees unqualified & 0.218 & $\mathrm{c}$ \\
Pensioners economically inactive & 11312.3 & $\mathrm{~b}$ & Pensioners economically active & 0.176 & $\mathrm{~d}$ \\
Unemployed & 6818.3 & $\mathrm{C}$ & Pensioners economically inactive & 0.136 & $\mathrm{e}$ \\
\hline
\end{tabular}

growth, especially for the high-skilled labour. These fiscal and social policy measures however negatively affected the pensioners and low-income groups, like the unemployed. Generally, there is apparent tendency of declining income differentiation in all groups over time, as shown in $G$ metric and variation (Tabs. I and III).

Two-way Anova revealed significant differences in mean per capita income among categories of economic activity of the household head (F-test $p<0.001$, Shapiro-Wilk $p=0.138$ ) and years ( $F$-test $p<0.001)$. In the linear model $\left(R^{2}=0.982\right)$, nonetheless, only distinct categories of the economic activity factor were allowed. Scheffé post-hoc tests detected three homogeneous groups, as shown in Tab. IV. The largest income level was seen in the group of qualified employees, whilst the lowest one belonged to the unemployed.

Regarding $G$ inequality coefficient, a separate two-way Anova $\left(R^{2}=0.991\right)$ confirmed significant differences among levels of economic activity ( $F$-test $p<0.001$, Shapiro-Wilk $p=0.642$ ) and years ( $F$-test $p<0.007$ ). Only non-overlapping levels of the economic activity factor were allowed. Five homogeneous groups were indicated by the Scheffé post-hoc test (see Tab. IV) with the largest per capita income inequality in the unemployed and self-employed and the lowest in economically inactive pensioners. 
The lowest income inequality occurred in the households, where economically inactive pensioner was the head and also in the group of low-qualified employees. This is likely related to higher similarity of retirement benefits, since about $70 \%$ pensions fall within the CZK 10000-15000 bracket. In the low-qualification employee category, nearly $87 \%$ households receive per capita income between CZK 5000 and 20000. The variation of income seems to be tied to the measure of location, which adds to the lower value of the Gini coefficient observed in these groups.

\section{Number of Children in Household}

Distribution of the equalized household incomes per capita shows important variation by the number of children in the household in all years under investigation. The highest mean and median income appear in households with no children and the values tend to drop, as the number of children in the household increases. The lowest level and slowest growth of per capita income was found in households with 3 or more children (Tabs. V and VI). This social and demographic group appears to be the most vulnerable to poverty and material deprivation, especially in scenario with only one parent present in the household. Further, the households with different number of children seem to be significantly impacted in terms of the income inequality: households with three or more children clearly have the largest value of Gini index (Tab. VII), compared with the remaining groups and apparently were the most severely hit by the austerity measures adopted by the government during and after the crisis. This is manifested by the lowest per capita income in combination with the highest income inequality in this group.

Scheffé pairwise comparisons for the per capita income levels and $G$ inequality measure are presented in Tab. VIII. For per capita income $\left(R^{2}=0.989\right)$, four homogeneous groups were created by the household size factor ( $F$-test $p<0.001$ ) with fulfillment of the normality assumption (ShapiroWilk $p=0.552$ ). For Gini inequality index, oneway Anova $\left(R^{2}=0.862\right)$ was estimated including the household size factor ( $F$-test $p<0.001)$ under normality (Shapiro-Wilk $p=0.213$ ) and variance homogeneity (Levene test $p=0.992$ ), since differences among years were nonsignificant. Two homogeneous groups by Scheffé test were detected separating the households with 3 or more children from the other categories.

\section{Education of Husband and Wife in Complete Households}

The following discrete criterion of the equalized income classification is the highest attained education of husband and wife in complete families

V: Descriptive statistics of per capita income of Czech households (CZK) by the number of children

\begin{tabular}{|c|c|c|c|c|c|c|}
\hline & Mean & SD & Mean & SD & Mean & SD \\
\hline One child & 10,336 & 5,365 & 11,953 & 6,953 & 13,046 & 6,639 \\
\hline Two children & 8,493 & 4,935 & 9,508 & 4,648 & 10,903 & 5,564 \\
\hline
\end{tabular}

VI: Median and medial of per capita income of Czech households (CZK) by the number of children

\begin{tabular}{|c|c|c|c|c|c|c|}
\hline \multirow{2}{*}{ Category } & \multicolumn{2}{|c|}{2008} & \multicolumn{2}{|c|}{2012} & \multicolumn{2}{|c|}{2016} \\
\hline & Median & Medial & Median & Medial & Median & Medial \\
\hline Childless & $11,145.6$ & $13,404.3$ & $13,232.8$ & $14,987.8$ & $14,059.8$ & $16,659.8$ \\
\hline One child & $9,281.5$ & $11,563.3$ & $10,929.1$ & $12,979.0$ & $12,065.5$ & $13,856.1$ \\
\hline Two children & $7,796.5$ & $8,855.7$ & $8,593.0$ & $10,153.4$ & $9,988.5$ & $12,285.0$ \\
\hline Three or more & $6,414.0$ & $7,845.2$ & $7,003.7$ & $8,785.0$ & $7,947.8$ & $9,848.2$ \\
\hline
\end{tabular}

VII: Per capita income inequality (G coefficients) for Czech households by the number of children

\begin{tabular}{llll}
\hline \multicolumn{1}{c}{ Category } & 2008 & 2012 & 2016 \\
\hline Childless & 0.247 & 0.227 & 0.223 \\
One child & 0.239 & 0.258 & 0.238 \\
Two children & 0.220 & 0.219 & 0.244 \\
Three or more children & 0.286 & 0.301 & 0.283 \\
\hline
\end{tabular}


VIII: Homogeneous groups based on two-tailed post-hoc test by Scheffé for differences in the mean per capita income (left) and concentration of income (right) among households with a specific number of children. Differences between household size levels with the same letter are not statistically significant $(\alpha=0.05)$

\begin{tabular}{lcclccc}
\hline \multicolumn{1}{c}{ Children } & Mean income & Groups & & Children & Average $G$ & Groups \\
\hline Childless & 14319.0 & $\mathrm{a}$ & & Three or more & 0.290 & $\mathrm{a}$ \\
One child & 11778.3 & $\mathrm{~b}$ & & One child & 0.245 & $\mathrm{~b}$ \\
Two children & 9634.7 & $\mathrm{C}$ & Childless & 0.232 & $\mathrm{~b}$ \\
Three or more & 7629.0 & $\mathrm{~d}$ & Two children & 0.228 & $\mathrm{~b}$ \\
\hline
\end{tabular}

IX: Descriptive statistics of per capita income of Czech complete households (CZK) by the top attained education of husband and wife $(P=$ Primary, $S=$ Secondary, $T=$ Tertiary $)$

\begin{tabular}{lrrrrrrr}
\hline \multirow{2}{*}{ Education of husband - wife } & \multicolumn{3}{c}{2008} & \multicolumn{3}{c}{2012} & \multicolumn{2}{c}{2016} \\
\cline { 2 - 7 } & Mean & SD & Mean & SD & Mean & SD \\
\hline P - P & 9,933 & 4,848 & 10,638 & 4,327 & 12,491 & 5,946 \\
\hline P - S & 11,153 & 4,711 & 11,551 & 4,950 & 13,646 & 5,623 \\
\hline S - P & 11,153 & 6,415 & 11,856 & 4,894 & 13,523 & 6,032 \\
\hline S - S & 12,301 & 6,736 & 13,658 & 6,750 & 14,989 & 6,899 \\
S - T & 14,186 & 8,419 & 15,243 & 7,784 & 16,746 & 8,500 \\
T - S & 14,516 & 7,212 & 17,466 & 9,493 & 18,358 & 9,193 \\
\hline T - T & 16,666 & 8,702 & 19,293 & 10,951 & 19,858 & 10,475 \\
\hline
\end{tabular}

X: Median and medial of per capita income of Czech households (CZK) by the top attained education of husband and wife $(P=$ Primary, $S=$ Secondary, $T=$ Tertiary $)$

\begin{tabular}{lrrrrrr}
\hline \multirow{2}{*}{ Education of husband - wife } & \multicolumn{2}{c}{2008} & \multicolumn{2}{c}{2012} & \multicolumn{2}{c}{2016} \\
\cline { 2 - 7 } & Median & Medial & Median & Medial & Median & Medial \\
\hline P - P & $9,103.8$ & $11,050.6$ & $10,172.4$ & $12,031.6$ & $11,825.0$ & $13,762.5$ \\
\hline P - S & $10,238.8$ & $12,466.7$ & $10,756.2$ & $13,148.1$ & $12,789.6$ & $14,587.6$ \\
\hline S - P & $9,626.0$ & $12,255.2$ & $11,098.3$ & $13,287.7$ & $12,606.5$ & $14,661.2$ \\
\hline S - S & $10,913.3$ & $13,765.2$ & $12,472.1$ & $15,066.4$ & $13,788.7$ & $16,782.9$ \\
\hline S - T & $12,300.0$ & $15,477.4$ & $13,461.5$ & $16,652.0$ & $15,042.2$ & $18,830.6$ \\
\hline T - S & $13,313.8$ & $16,403.8$ & $14,983.6$ & $21,005.4$ & $16,699.2$ & $20,476.2$ \\
\hline T - T & $14,355.3$ & $18,636.4$ & $16,428.6$ & $22,078.7$ & $17,328.8$ & $22,559.5$ \\
\hline
\end{tabular}

with observed education levels primary (P), secondary $(\mathrm{S})$ or tertiary $(\mathrm{T})$. There is a clear indication in Tabs. IX and X that formal qualification increases the absolute level of per capita income, although the increase in income appears higher, when husband is the more qualified member of the household. As expected, a general tendency of income increase with time is present in all combinations, together with gradually reduced value of Gini inequality metric (Tab. XI). In 2008, the largest inequality was found in the families of husband and wife with secondary and tertiary education, respectively. In later years, however, the largest $G$ index was observed in households, where both husband and wife received tertiary education.

Presence of adult in the household with tertiary education markedly brings an opportunity for
XI: Per capita income inequality (G coefficients) for Czech households by the top attained education of husband and wife $(P=$ Primary, $S=$ Secondary, $T=$ Tertiary)

\begin{tabular}{llll}
\hline Education of husband - wife & 2008 & 2012 & 2016 \\
\hline P - P & 0.219 & 0.210 & 0.233 \\
P - S & 0.215 & 0.224 & 0.212 \\
S - P & 0.243 & 0.215 & 0.228 \\
S - S & 0.263 & 0.250 & 0.240 \\
S - T & 0.284 & 0.253 & 0.262 \\
T - S & 0.254 & 0.284 & 0.263 \\
T - T & 0.268 & 0.293 & 0.275 \\
\hline
\end{tabular}

higher remuneration, a reduced chance for material deprivation and poverty, but at the expense of 
greater income differentiation, i.e. inequality. Brázdilová and Švarcová (2015) confirm that tertiary education is strongly associated with raising income levels, but also with larger concentration of the revenue. For illustration, in the upper decile of the equalized income (year 2012), 35.2\% households have a tertiary educated member, while in the first decile, only $2.7 \%$ have some college education. Tertiary educated individuals represent about $16 \%$ of the overall population in Czechia, but receive $22 \%$ of the equalized income. Primary educated subjects, on the contrary, constitute $10 \%$ of the population, but receive only $7.8 \%$ income. In other words, 20\% richest with tertiary education receive 3.6 times more than $20 \%$ poorest of the same group. It should be added, nonetheless, that differences between the rich and the poor in the Czech Republic are still among the lowest in OECD countries.

Tab. IX shows that in combinations involving parent with low education, the dispersion of income seems visibly depressed. Generally, the lowest income inequality ( $G$ index) can be seen in household categories involving a family member with primary education. It could be hypothesized that low educated workforce seems more often to find employment in domestic firms of small size and located in rural areas, that usually attain lower productivity and can afford to provide lower benefits. Brázdilová and Švarcová (2015) report that $20 \%$ richest in the primary education group receive only 2.8 times more than $20 \%$ poorest. The quintile ratio in their study showed clear tendency to increase with higher levels of education attained.

A linear model of two-way Anova was prepared for the $G$ inequality variable explained by household educational groups formed by the highest attained education of husband and wife, respectively, and the year factor. While the factor of educational group was statistically significant ( $F$-test $p<0.001$ ), second $F$-test $p$-value for the year effects was above the $5 \%$ test size boundary and consequently year factor had to be removed turning the model into one-way Anova $\left(R^{2}=0.828\right.$, Shapiro-Wilk $p=0.534$, Levene test $p=0.974$ ). Scheffé post-hoc test for inequality differences by household educational group is presented in Tab. XII. The tests proved that rising education of the husband and wife generally led to higher levels of the $G$ index meaning more inequality of per capita income. In addition, combinations, where husband had higher education than wife produced on average higher degree of per capita income inequality compared to the reversed variant. Totally, three homogeneous groups were formed by the Scheffé pairwise tests. The lowest mean $G$ index was seen in households, where husband had just primary education; the highest inequality was observed in households with husband and wife having tertiary education. Data for mean incomes showed other than normal distribution, which precluded application of the linear model.
XII: Homogeneous groups based on two-tailed post-hoc test by Scheffé for differences in the concentration of per capita income among households grouped by the highest attained education of husband and wife ( $P$ = Primary, $S=$ Secondary, $T=$ Tertiary). Differences between household categories with the same letter are not statistically significant $(\alpha=0.05)$

\begin{tabular}{lcc}
\hline Education of husband - wife & Average $G$ & Groups \\
\hline T - T & 0.278 & a \\
T - S & 0.267 & ab \\
S - T & 0.266 & ab \\
S - S & 0.251 & abc \\
S - P & 0.229 & bc \\
P - P & 0.221 & c \\
P - S & 0.217 & c \\
\hline
\end{tabular}

\section{NUTS 3 Geographic Regions}

The remaining factor influencing magnitude of the household per capita income investigated in this study is geography. The differences in income level among regions exist essentially due to uneven allocation of investment, demographic factors like age groups or population density, labor qualification or available infrastructure in the NUTS 3 administrative regions of the country. Figs. 3, 4 show indicators of income location and concentration, respectively, for the NUTS 3 units. Cartograms for per capita income (mean, median, medial and $G$ index) by the NUTS 3 administrative regions in 2016 are available in Figs. 5-8, in respective order.

The largest level of per capita household income was found in Prague, Středočeský and Plzeňský regions in all years; the lowest levels, on the other hand, were observed in regions Olomoucký, Zlínský, Moravskoslezský and Pardubický. Tichá (2015) explains that the largest median and mean income is often found in regions with the lowest unemployment. The Gini coefficient was gradually decreasing with time, which implies lesser income differentiation and greater equality. In 2008, the largest income inequality was found in Ústecký region $(G=0.281)$, however, in the following years, it occurred in Prague, the country's capital city $(G=0.284$ in 2012 and $G=0.272$ in 2016). Higher income inequality also existed in the Středočeský region in all years explored in this study. Also, it appears that economic and social measures enacted by the Czech government helped reduce the growing income inequality and risk of poverty in Ústecký region in 2008, as the Gini metric successively dropped in the following years.

The role of Prague, as the country's economic powerhouse is well proven: although Prague represents only $12 \%$ of the country's population, its regional GDP accounts for 27\%. On the other hand, Moravskoslezský and Ústecký regions lagged behind in economic prosperity, primarily 


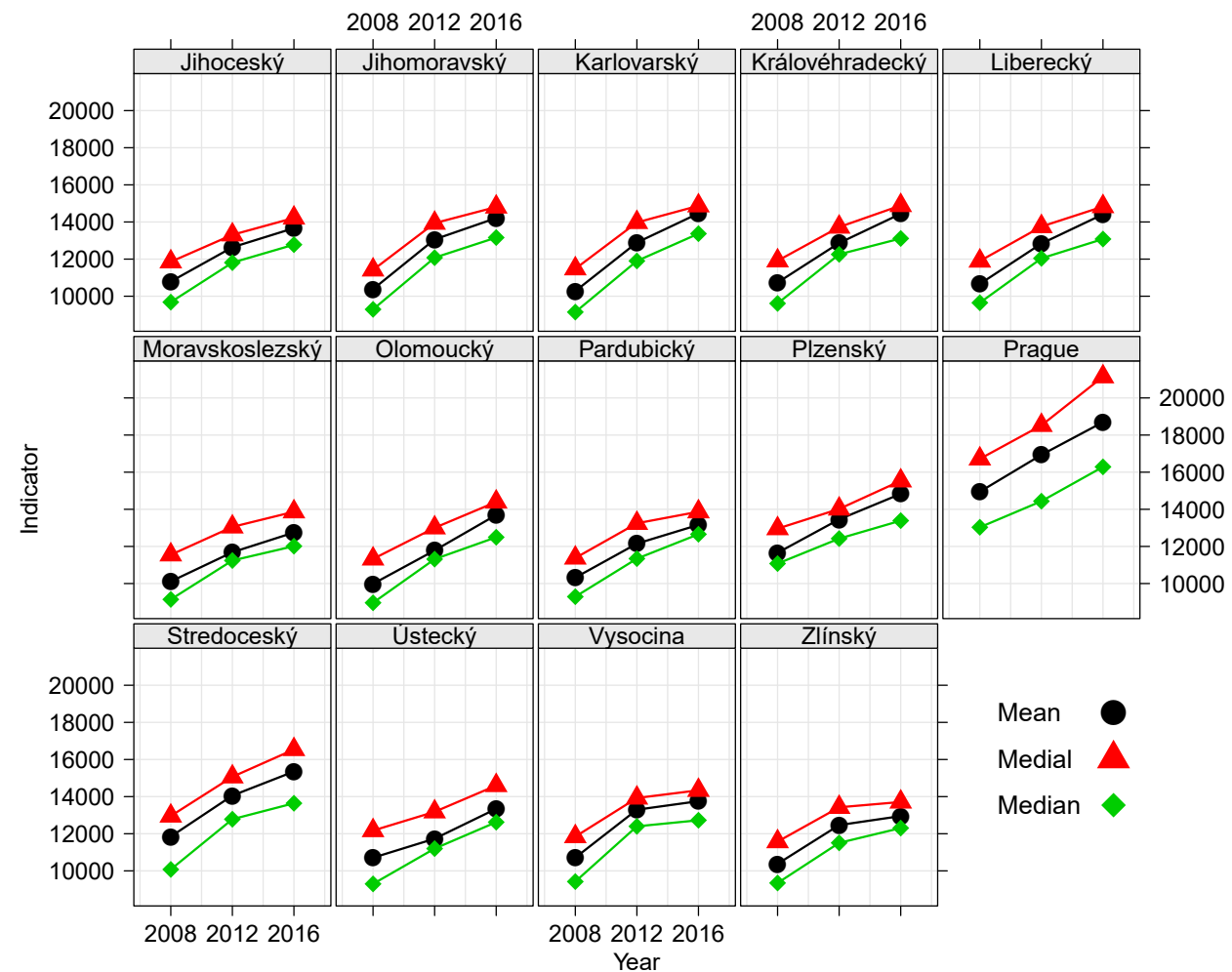

3: Mean, median and medial for the per capita household income (CZK) by the administrative regions NUTS 3 in 2008, 2012 and 2016

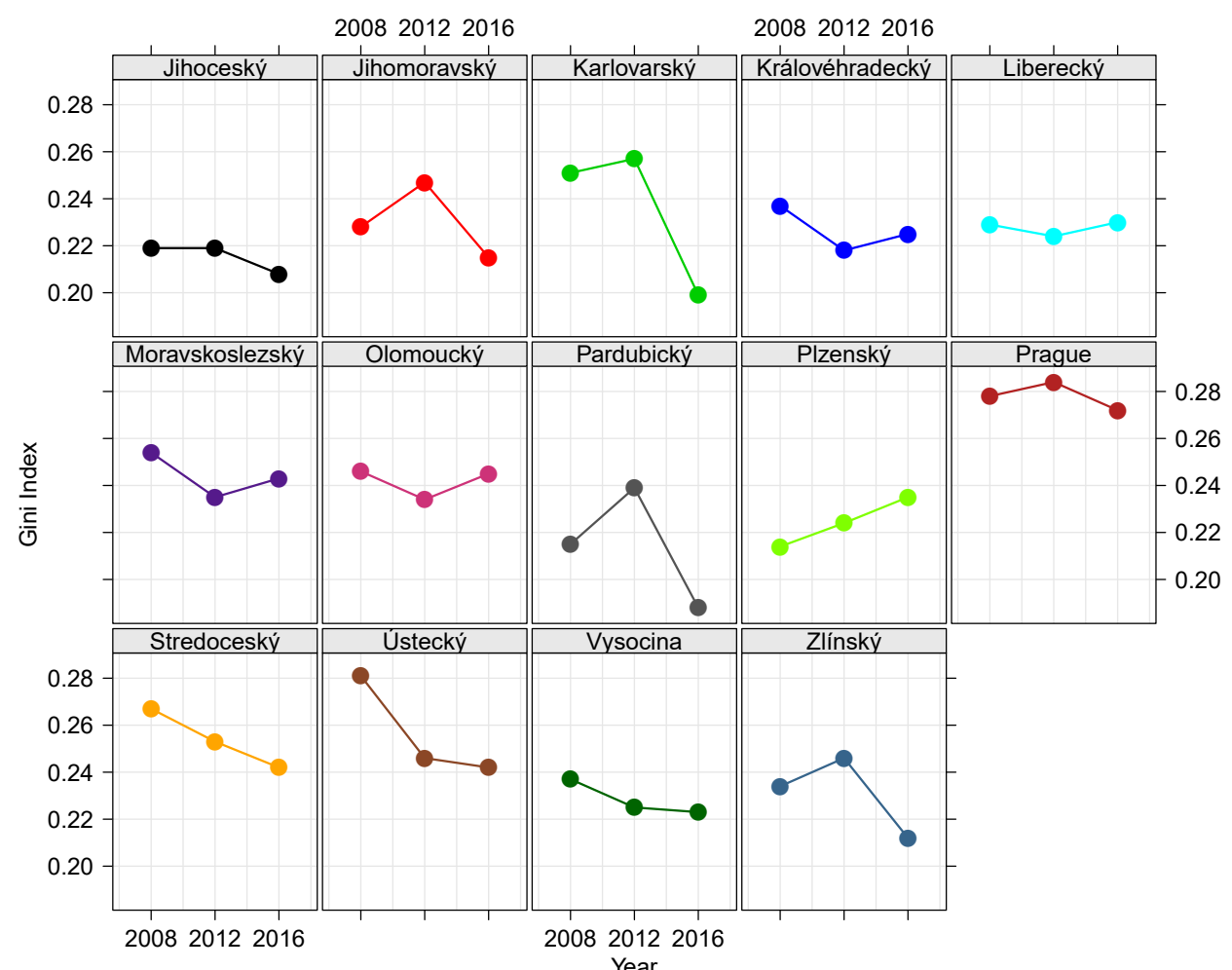

4: Gini coefficient for the per capita household income (CZK) by the administrative regions NUTS 3 in 2008, 2012 and 2016 


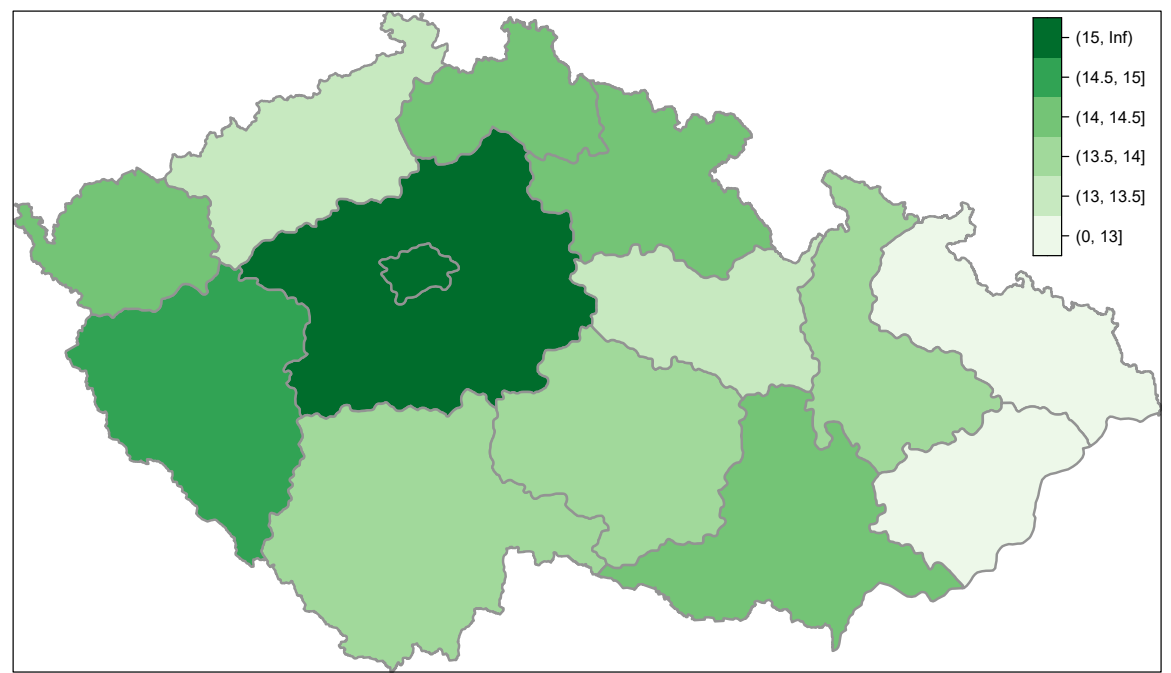

5: Mean per capita income (CZK thous.) by the Czech administrative regions NUTS 3 in 2016

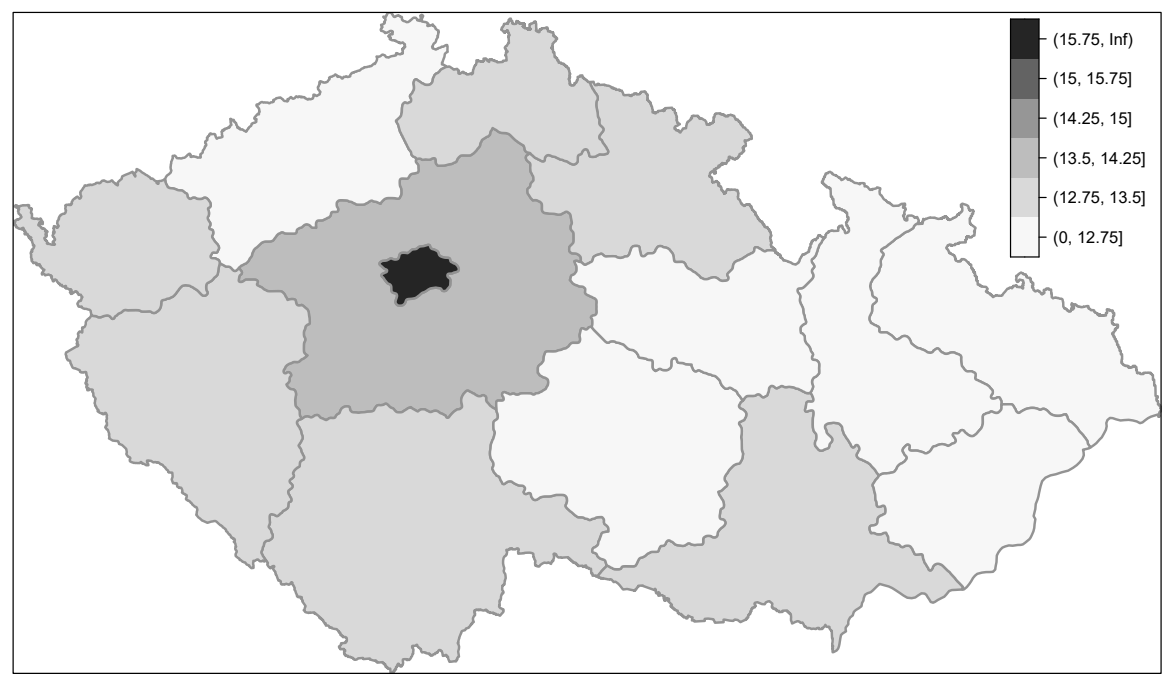

6: Median per capita income (CZK thous.) by the Czech administrative regions NUTS 3 in 2016

due to high proportions of unqualified labor, legacy of heavy industry, social instability and absence of infrastructure and investments. Regions Ústecký, Olomoucký, Zlínský and Moravskoslezský were generally known for large proportion of households experiencing income poverty. Prague and Středočeský regions, on the contrary, show much smaller percentage of income poverty. The lowest Gini coefficients (income inequality) in 2016 were nonetheless found in regions Pardubický (0.188), Karlovarský (0.199) and Jihočeský (0.208). The results for all years, however, do not indicate strong differences in income concentration among the NUTS 3 regions in the country. It appears that regions of the Czech Republic could be divided in two distinct areas: the first with low proportion of material deprivation including majority of the NUTS 3 regions and the second with high material deprivation rates with the regions Moravskoslezský and Ústecký.
In the whole country, the Gini inequality measure noticeably decreased between 2008, 2012 and 2016. It could be explained by raising economic prosperity and increased social transfers to the most underprivileged household groups. Some reduction of income inequality was realized via repeated raising of the minimum wage levels, increase of pensions and social transfers enacted by the leftwing Czech government. Others could be attributed to the current phase of the economic cycle, since the economic boom after 2014 greatly increased demand for the low income labor and consequently led to reduced unemployment. During this period, wages in the low-income group climbed up at faster rate than in the high income group (czso. $\mathrm{cz}$ ). A similar observation of higher income growth in the low income cohort during economic boom before 2008 was reported in Malá and Červená (2012). 


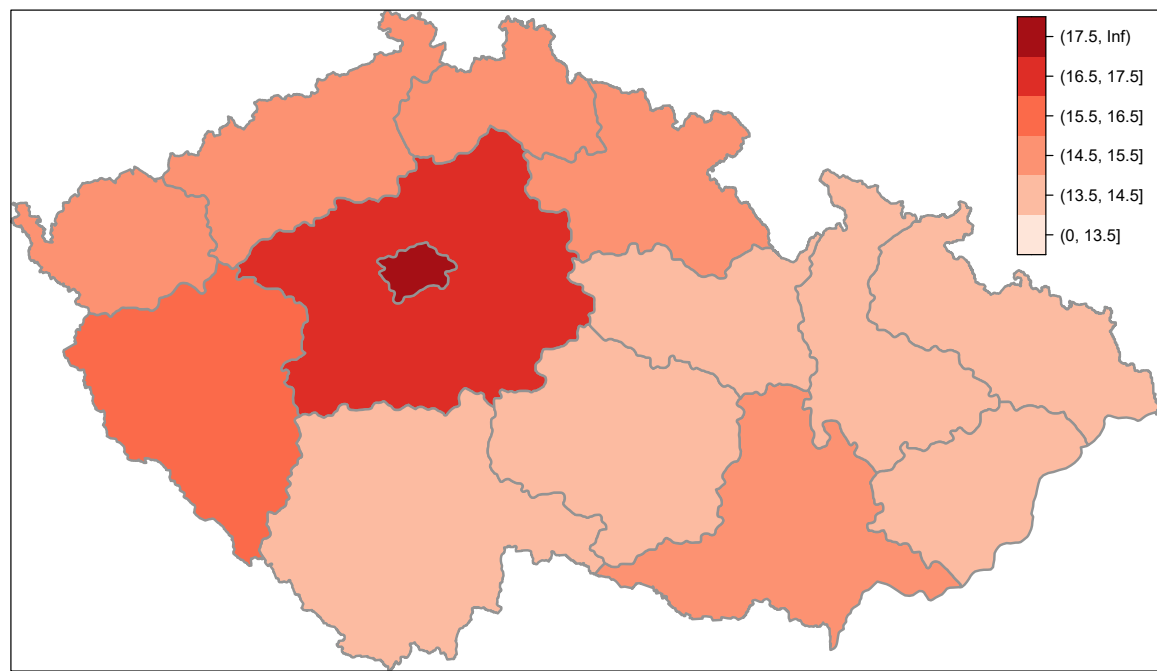

7: Medial per capita income (CZK thous.) by the Czech administrative regions NUTS 3 in 2016

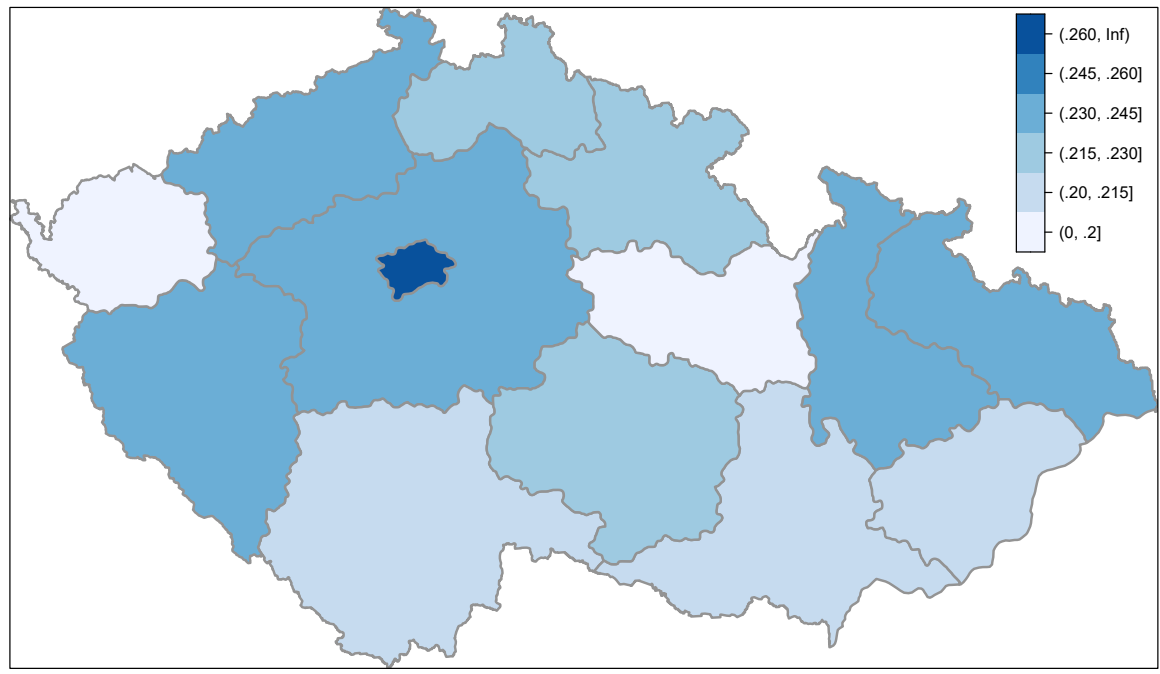

8: Gini index for per capita income by the Czech administrative regions NUTS 3 in 2016

In the current study, we carried out tests for the differences in the mean equalized per capita income among the NUTS 3 regions ( $p<0.001$ ) and years $(p<0.001)$ via two-factor Anova F-tests $\left(R^{2}=0.98\right)$ after establishing residual normality with ShapiroWilk test $(p=0.962$ ). Four homogeneous groups $(\alpha=0.05)$ were produced by Scheffé post-hoc test for levels of the NUTS 3 regions factor, as shown in Tab. XIII. Three homogeneous income groups were found in Tab. XIV for the year factor. Superiority of per capita income levels in Prague and Středočeský region over the rest of the country were clearly established. Further, a significant rising tendency of per capita income tested positive among 2008, 2012 and 2016 as shown in Tab. XIV.

A similar two-way Anova model $\left(R^{2}=0.737\right)$ and pairwise comparisons were also performed for the per capita income concentration index $G$, as normal distribution of the residual terms was not rejected (Shapiro-Wilk $p=0.558$ ). The partial
F-tests of the global hypotheses corroborated statistical significance of the NUTS 3 region factor ( $F$-test $p<0.001)$ and year factor (F-test $p=0.016)$. Homogeneous groups for the Scheffé post-hoc test for differences among the NUTS 3 regions are displayed in Tab. XIII; homogeneous level grouping based on the Scheffé pairwise comparisons among years is presented in Tab. XIV. Two homogeneous groups were formed among levels of the NUTS 3 factor, where differences in income concentration between Prague, on one hand, and Pardubický or Jihočeský regions, on the other hand, received the most statistical significance. Generally, high levels of income inequality index were observed in administrative regions with large social instability and internal migration. Two homogeneous groups were produced for the year factor: a clear declining tendency in household income concentration over the researched period was established with $\alpha=0.05$. 
XIII: Homogeneous groups based on two-tailed post-hoc test by Scheffé for differences in the mean per capita income (left) and concentration of income (right) among the administrative regions NUTS 3. Differences between regions with the same letter are not statistically significant $(\alpha=0.05)$

\begin{tabular}{|c|c|c|c|c|c|}
\hline NUTS 3 & Mean income & Groups & NUTS 3 & Average $G$ & Groups \\
\hline Prague & 16859.0 & a & Prague & 0.278 & a \\
\hline Stř̌edočeský & 13751.7 & $\mathrm{~b}$ & Ústecký & 0.256 & $a b$ \\
\hline Plzeňský & 13315.0 & $\mathrm{bc}$ & Středočeský & 0.254 & $a b$ \\
\hline Královéhradecký & 12681.0 & bcd & Moravskoslezský & 0.244 & $a b$ \\
\hline Liberecký & 12637.3 & bcd & Olomoucký & 0.242 & $a b$ \\
\hline Vysočina & 12587.3 & bcd & Karlovarský & 0.236 & $a b$ \\
\hline Jihomoravský & 12551.7 & bcd & Zlínský & 0.231 & $a b$ \\
\hline Karlovarský & 12543.3 & bcd & Jihomoravský & 0.230 & $\mathrm{ab}$ \\
\hline Jihočeský & 12365.7 & bcd & Vysočina & 0.228 & $a b$ \\
\hline Zlínský & 11931.7 & $\mathrm{~cd}$ & Liberecký & 0.228 & $a b$ \\
\hline Ústecký & 11928.0 & $\mathrm{~cd}$ & Královéhradecký & 0.228 & $\mathrm{ab}$ \\
\hline Pardubický & 11877.7 & $\mathrm{~cd}$ & Plzeňský & 0.224 & $a b$ \\
\hline Olomoucký & 11820.7 & $d$ & Jihočeský & 0.215 & $\mathrm{~b}$ \\
\hline Moravskoslezský & 11515.7 & $d$ & Pardubický & 0.214 & $\mathrm{~b}$ \\
\hline
\end{tabular}

XIV: Homogeneous groups based on two-tailed post-hoc test by Scheffé for differences in the mean per capita income (left) and concentration of income (right) among years. Differences between years with the same letter are not statistically significant $(\alpha=0.05)$

\begin{tabular}{|c|c|c|c|c|c|}
\hline Year & Mean income & Groups & Year & Average $G$ & Groups \\
\hline 2016 & 14265.8 & a & 2008 & 0.242 & a \\
\hline 2012 & 12989.7 & $\mathrm{~b}$ & 2012 & 0.239 & $a b$ \\
\hline 2008 & 10965.7 & c & 2016 & 0.227 & $\mathrm{~b}$ \\
\hline
\end{tabular}

\section{CONCLUSION}

The issue of household income inequality is urgent in every economy. Historically, the Czech Republic has one of the lowest levels of income inequality among the OECD or European countries with a tradition of generous social policy, healthcare accessible to the general public and income redistribution. It is reflected in more even spread of the country's wealth, good health of the population, low crime rate and gradually increasing life expectancy in males and females. The current study discovered, that the Czech Republic shows anomalies in household per capita income in several areas, however, with improving tendency over time, since during 2008 and 2016 the income distributions became more equalized. The discrepancies, however, tend to persist in specific groups, such as economically inactive pensioners, widowed elderly dwelling in isolation, uneducated workforce, households of mothers taking care for multiple dependents and the longterm unemployed. Nonetheless, the level of income inequality $G$ index rarely exceeded 0.35 upper boundary in these groups.

Geographically, the inhabitants of Ústecký or Moravskoslezský regions more likely experienced poverty, deprivation and social exclusion to a large extent, while prevailing populations of Prague, Středočeský or Plzeňský regions were exposed to relative economic well-being. It is therefore recommended that the endangered regions or social groups be closely monitored by the central authorities, as they may be source of social instability and suffer from undesirable social rejection. In history, due to effective measures adopted by the Czech government, a serious social instability was prevented in the Ústecký region; recent upward adjustments of pensions, maternity benefits, minimum wage and abolition of healthcare copayments helped reduce income inequality in the most exposed groups.

In context of findings presented in this paper, the government social and financial assistance to households should be gradually retargeted at the problem groups or geographical regions, while 
restricting broad efforts to redistributing incomes, providing fee waivers or social benefits to the general population, who in general does not need it. It should be emphasized, that one of the most effective tools of combating poverty and social exclusion is continuous and unrestricted access to education and retraining. It is one of the main findings of this paper that mainly the educated segments of the population experience the most economic and social well-being and on the contrary, the uneducated ones are at the most risk of poverty. Since the requirements of the labor market of qualification continually change, the educational system should effectively respond to the new challenges and help maintain ability of the individuals to stay on the job market, a vital requisite to healthy economic condition of the households.

\section{Acknowledgements}

The authors appreciate kind assistance of the Czech Statistical Office, who provided data for this study. Thanks are also expressed to the anonymous reviewer for comments and suggestions that helped improve the paper.

\section{REFERENCES}

ATKINSON, A. B. 2016. Ekonomika nerovnosti. BizBooks.

BALTAGI, B. H. 2005. Econometric analysis of panel data. $3^{\text {rd }}$ Edition. London: John Wiley \& Sons.

BELABED, C. A. and HAKE, M. 2018. Income inequality and trust in national governments in central, eastern and southeastern Europe. Working Papers No. 222. Austrian Central Bank.

BRÁZDILOVÁ, M. and ŠVARCOVÁ, P. 2015. Income inequality by highest attained education in the Czech Republic. Statistika: Statistics and Economy Journal, 95(4): 5-16.

BROWN, M. C. 1994. Using Gini-style indices to evaluate the spatial patterns of health practitioners; theoretical considerations and an application based on the Alberta data. Social Science and Medicine, 38(9): 1243-1256.

BIRČIAKOVÁ, N., STÁVKOVÁ, J. and ANTOŠOVÁ, V. 2013. Income (in)justice in the Czech Republic. Danube, 4(3): 185-199.

CHARLES-COLL, J. A. 2011. Understanding income inequality: concept, causes and measurement. International Journal of Economics and Management Sciences, 1(3): 17-28.

COWELL, F. A. 2000. Measurement of inequality. In: ATKINSON, A. B. and BOURGUIGNON, F. (Eds.). Handbook of Income Distribution. Amsterdam: North Holland.

DE MENDIBURU, F. 2020. Agricolae: Statistical procedures for agricultural research. R package version 1.3-3. Available at: https://CRAN.R-project.org/package=agricolae [Accessed: 2020, June 15].

GRAAFLAND, J. and LOUS, B. 2018. Economic freedom, income inequality and life satisfaction in OECD countries. Journal of Happiness Studies, 19(7): 2071-2093.

LONGFORD, N. T., PITTAU, M. G., ZELLI, R. and MASSARI, R. 2010. Measures of poverty and inequality in the countries and regions of EU. Working papers 182. ECINEQ. Society for the study of economic inequality.

MALÁ, Z. and ČERVENÁ, G. 2012. The relation and development of expenditure inequality and income inequality of Czech households. Economic Annals, 57(192): 55-78.

MINAŘÍK, B., BORU゚VKOVÁ, J. and VYSTRČIL, M. 2013. Analýzy v regionálním rozvoji. Praha: Professional Publishing.

OTT, L. R. 1993. An introduction to statistical methods and data analysis. $4^{\text {th }}$ Edition. Belmont: Wadsworth Publishing.

PETRÚŠEK, I. 2018. Perceptions of income inequality and preferences regarding income distribution in the Czech Republic [in Czech: Vnímání př́jmových nerovností a preference ohledně rozdělení př́jmů v České republice]. Politická ekonomie, 66(5): 550-568.

R DEVELOPMENT CORE TEAM. 2020. R: A language and environment for statistical computing. Vienna, Austria: R Foundation for Statistical Computing.

SARKAR, D. 2008. Lattice: multivariate data visualization with R. New York: Springer.

SCHEFFÉ, H. 1959. The analysis of variance. New York: John Wiley \& Sons.

STÁVKOVÁ, J. and ANTOŠOVÁ, V. 2013. Income situation and living conditions of inhabitants in the Czech Republic. Folia Universitatis Agriculturae et Silviculturae Mendelianae Brunensis. $1^{\text {st }}$ Edition. Brno: Mendel University in Brno.

TICHÁ, M. 2015. Česká ekonomika na prahu 21. století v kontextu společenského vývoje. $2^{\text {nd }}$ Edition. Ostrava: VŠB-TU Ostrava.

WILKINSON, R. G. and PICKETT, K. 2010. The spirit level: why equality is better for everyone. London: Penguin Books. 
ZEILEIS, A. 2014. ineq: Measuring inequality, concentration and poverty. R package version 0.2-13. Available at: https://cran.r-project.org/package=ineq [Accessed: 2019, July 10].

Contact information

Markéta Hnízdilová: xhnizdil@mendelu.cz

Václav Adamec: vadamec@mendelu.cz 